\title{
高層建物の風応答予測の不確かさ伝播に関する研究 UNCERTAINTY PROGAGATIONS ON WIND RESPONSE ANALYSIS OF TALL BUILDINGS
}

\author{
野田博*
}

Hiroshi NODA

\begin{abstract}
In this paper, uncertainty propagation analysis was conducted to investigate accuracy of wind response prediction of high raise buildings and influence of uncertainties in each parameter which are used in wind response analysis. A new parameter which is "related sensitive coefficient" concerning propagation was defined to consider wind response prediction more analytically and efficiently. The values of uncertainties of each parameter were also investigated on the basis of literature. Furthermore, the accuracy of wind response predictions obtained by spectra-modal analysis was revealed from investigation of related sensitive coefficients and values of uncertainties of each parameter.

Regarding the mean and maximum fluctuating response displacement, uncertainties of natural frequency and design wind velocity affect to response results strongly, whereas uncertainties of damping ratio and wind force spectrum affect slightly. The largest values of uncertainties in whole parameter of wind response analysis are uncertainties of damping ratio and wind force spectrum. Minimum value is uncertainty in design wind velocity.

The uncertainty propagation value to the maximum response displacement was the highest for the natural frequency. That is, the uncertainty of the maximum response displacement was largely dependent on the uncertainty of the natural frequency. The damping ratio and the resonance wind force spectrum had high uncertainty. However, their propagation values were low because their relative sensitivity coefficients were low.
\end{abstract}

Keywords : Wind response analysis, Spectra-modal analysis, Uncertainty, Propagation \& combined, Reliability 風応答予測，スペクトルモーダル解析，不確かさ，伝播と合成，信頼性

1. はじめに

建築物の耐風設計では，応力解析や振動応答解析等を実施し，設 定した風荷重レベルにおける部材応力が使用する部材耐力を上回ら ないことを確認する。このとき, 数多くの基準值, 実験值あるいは 経験值に基づいた值を用いて風荷重レベルや部材応力を算定する。 これらの諸量は, 種々の原因により「不確かさ」を有している。「不 確かさ」とは, 多くの分野で一般的に用いられている「誤差」や「精 度」に対応するもので, 計量・測量分野で統一された計測データの 信頼性の表現方法であり, 結果に付随したばらつきを特徴つけるパ ラメーター（真の值が存在する範囲）として用いられる。例えば, 耐風設計で重要な解析項目である風応答解析では, 種々の建物構造 特性，風洞実験結果，あるいは気象観測データに基づく設計風速が 用いられるが，これらは全て「不確かさ」を有し，「不確かさ」を有 する諸量を用いて風応答解析を行えば, 「不確かさ」は伝播され, そ
の解析結果も「不確かさ」を有する。この風応答解析結果の「不確 かさ」はどの程度なのか, あるいは解析結果に大きく影響を及ぼす のはどの因子なのかを把握することは, 風応答解析結果を耐風設計 に適用する場合において大変重要である。

設計資料の信頼性を確認することを目的として，これまで数多く の研究がされている例えば 1) 4)。Pagnini ${ }^{11}$ は, 固有周期と減衰定数のば らつきが風方向振動にどの程度影響しているかを調べている。

Pagnini \& Solari ${ }^{21}$ は風の乱れの統計量の評価方法により風応答解析 に用いる変動風力が大きく異なることを指摘し，変動風のばらつき が建物応答予測にどの程度伝播するかを調べている。その際変動風 力は，乱れの統計量を変化させ，モンテカルロ法により生成してい る。Saranyasoonton \& Manue $\left.\right|^{31}$ は発電用風車に作用寸る荷重算定に用 いられる風の乱れの統計量モデルのばらつきが，風荷重算定にどの 程度影響寸るかを検討している。その際 POD 解析を利用して風の乱 


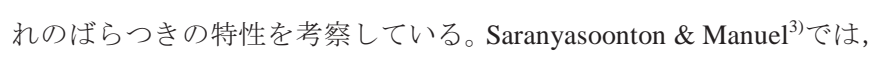
風車設計用風荷重のばらつきは風の乱れのばらつきよりも小さいと 結論付けている。平井ら ${ }^{4}$ は, 風洞実験により得られる 1 次一般化 変動風力のばらつきとその風力を用いた場合の風応答予測值のばら つきを変動係数とアンサンブル平均により検討している。

地震動と建物応答に関しても種々検討されている例えば 5) 8)。桑村 ら ${ }^{5}$ は, モンテカルロ法により作成した数多くの部材耐力の異なる 建物構造骨組の標本を生成し, 部材耐力のばらつきが建物骨組みの 崩壊メカニズムに及ぼす影響を考察している。また地震動のばらつ きと建物質量の高さ方向分布のばらつきも同様の手法により検討し ている。桑村ら ${ }^{5)}$ では地震動ならびに建物質量の高さ方向分布のば らつきよりも部材耐力のばらつきの方が建物の全体崩壊メカニズム に与える影響が大きいことを示した。宅間ら ${ }^{61}$ は建物の固有周期の ばらつきが地震動に対する弾性応答スペクトルに与える影響につい て考察している。加速度応答倍率のばらつきは, 建物固有周期のば らつきよりも大きくなることを示した。松尾ら ${ }^{71}$ は, 建物の各部材 の降伏応力のばらつきが建物構造骨組のエネルギー吸収に与える影 響について, 建物の層数, スパン数, 柱梁耐力比を変化させて考察 している。各部材の降伏応力はモンテカルロ法により 5000 個生成し ている。市橋ら ${ }^{81}$ は, 地震動の非定常性をより合理的に設計地震動 に反映させることを目的とし, 種々の時間周波数特性を有する模擬 地震波群を合成しこれらの弾塑性系振動モデルの応答值のばらつき を考察している。検討の結果, 最大応答変位に大きなばらつきを有 することを指摘した。これらの既往の研究では, 外力, 減衰定数, あるいは固有周期などのある一つの因子のばらつきと建物応答に及 ぼす影響の考察が多く、また検討手法はモンテカルロ法を利用して 因子のばらつきを再現して数多くの実計算を実施している。

本論文では, 風応答解析の信頼性を系統的に検証するため, 計測 值の信頼性評価 ${ }^{9), 10)}$ で用いられている不確かさ伝播解析ならびに合 成 ${ }^{11)}$ 風応答解析に応用し, 風応答解析で用いる種々のパラメータ 一の「不確かさ」が解析結果に及ぼす影響を定量的に明らかにする。 また, 種々のパラメーターの「不確かさ」を既往の文献により調查 し, 種々のパラメーターの「不確かさ」による応答解析結果の「不 確かさ」, あるいはそれらの合計がどの程度かを調べた。

なお, 同様な研究として野田ら ${ }^{12)}$ が風環境評価結果の信頼性に関 して検討しているが, 本研究はその手法を風応答解析結果の信頼性 に適用したものである。

本論文は注 1),注 2)を加筆・修正したものである。

\section{2. 不確かさの伝播と合成}

不確かさを有する種々のパラメーター(以下，因子という。) を用 いて評価值を算出するとき, その評価值に含まれる不確かさを求め るには, 各因子に含まれる不確かさの見積もりと, 各因子の不確か さの伝播と合成を計算すればよい11。不確かさの伝播と合成は以下 の手順で算出できる。ある值 $x$ を用いて評価值 $f(x)$ を算出すること を考える。ある值 $x$ が有する不確かさ量を $\delta x$ とすると, 評価值の不 確かさ量, 寸なわち不確かさ伝播量 $\delta f(x)$ は下式となる。

$$
\delta f(x)=\left|\frac{d f(x)}{d x}\right| \delta x
$$

右辺の微係数の絶対值は感度係数と呼ばれ，この值により因子の 不確かさが増幅あるいは減衰して伝播するか決定する。

複数の因子を $x_{i}(\mathrm{i}=1,2, \cdots \mathrm{N})$ とし, これらの不確かさを $\delta x_{i}$ とする。 複数の因子を用いて評価值 $f\left(x_{i}\right)(\mathrm{i}=1,2, \cdots \mathrm{N})$ を計算する場合, $x_{i}$ が互い に独立かつランダムであるとすれば， $f\left(x_{i}\right)$ の合成不確かさ $\delta f\left(x_{i}\right)$ は以 下の通りとなる。

$$
\delta f\left(x_{i}\right)=\sqrt{\sum_{i=1}^{N}\left(\frac{\partial f\left(x_{i}\right)}{\partial x_{i}} \delta x_{i}\right)^{2}}
$$

不確かさ $\delta x_{i}$ が独立でなく, 互いに相関がある場合には， $f\left(x_{i}\right)$ の合 成不確かさ $\delta f\left(x_{i}\right)$ は以下で求めることが出来る。

$$
\delta f\left(x_{i}\right)=\sqrt{\sum_{i=1}^{N}\left(\frac{\partial f\left(x_{i}\right)}{\partial x_{i}} \delta x_{i}\right)^{2}+2 \sum_{i=1}^{N-1} \sum_{j=i+1}^{N} \frac{\partial f\left(x_{i}\right)}{\partial x_{i}} \frac{\partial f\left(x_{j}\right)}{\partial x_{j}} \sigma_{i, j}}
$$

ここで， $\sigma_{i, j}$ は $x_{i}$ と $x_{j}$ の共分散である。ただし，(3)式は $x_{i}$ の不確 かさ $\delta x_{i}$ に標準偏差を用いた場合に成立する。

本研究では風応答解析の不確かさ伝播量を検討する際には, 各因 子の影響を相対評価しやすいように，各因子の不確かさ伝播量を下 式の相対不確かさ伝播量で表す。

$$
R u_{x i}=\frac{\delta f\left(x_{i}\right)}{f\left(x_{i}\right)}=\frac{|\partial f(x) / \partial x| \delta x_{i}}{f\left(x_{i}\right)}
$$

ここで, $R u_{x i}$ は相対不確かさ伝播量である。相対不確かさ伝播量 を(4)式で定めると, 全ての場合において下式のように整理できる。

$$
R u_{x i}=C v_{x i} \cdot \frac{\delta x_{i}}{x_{i}}
$$

ここで, $\delta x_{i} / x_{i}$ は因子の相対不確かさ量, $C v_{x i}$ は相対不確かさ量に おける感度係数であり相対感度係数と定義する。

このように定義することにより，例えば，「因子 A は，その值に 対して $a \%$ の不確かさを有するとき, 風応答予測值にはその予測值 に対して $\left(C v_{x i} \cdot a\right) \%$ 不確かさを有する。」と理解することができる。

本論文では, 不確かさ量 $\delta x_{i}$ として $x_{i}$ の標準偏差 $\sigma_{x i}$ を用いる。こ の場合, 不確かさ量は標準不確かさ量となり, 相対不確かさ量 $\delta x_{i} x_{i}$ は変動係数 $(=$ 標準偏差／期待值 $)$ に相当する。ただし, 建物固有周 期と建物減衰定数の不確かさ量については, 後述の理由により変動 比を用いる。

\section{3. 風応答解析の不確かさの伝播}

\section{1 対象とする風応答解析}

本論文で対象とする風応答解析は，一般的に用いられている線形 応答を仮定したスペクト・ルモーダル解析とする。一次振動のみを対 象とすれば, 最大応答変位, 最大応答加速度, ならびに平均変位は 以下の通りとなる。

$$
y_{\max }=g_{p} \frac{\sigma_{f}}{\left(2 \pi n_{0}\right)^{2} m} \sqrt{1+\frac{\pi}{4 h} \cdot \frac{n_{0} S\left(n_{0}\right)}{\sigma_{f}^{2}}}
$$




$$
\begin{aligned}
& \ddot{y}_{\max }=g_{p} \frac{\sigma_{f}}{m} \sqrt{\frac{\pi}{4 h} \cdot \frac{n_{0} S\left(n_{0}\right)}{\sigma_{f}^{2}}} \\
& \bar{y}=\frac{C_{f} \rho U^{2} B H}{2\left(2 \pi n_{0}\right)^{2} m}
\end{aligned}
$$$$
g_{p}=\sqrt{2 \ln \left(600 n_{0}+1.2\right)} \quad, \sigma_{f}=C_{f}^{\prime} \frac{1}{2} \rho U^{2} B H
$$

ここで, $y_{\max }$ : 最大応答変位, $\ddot{y}_{\text {max }}$ : 最大応答加速度, $\bar{y}$ :平均変位, $n_{0}$ : 建物一次固有振動数, $m$ :一般化質量, $h$ :減衰定数, $B, H$ :それぞれ 建物幅と高さ, $U$ : 設計風速, $\rho$ : 空気密度, $S\left(n_{0}\right)$ :一般化変動風力の基 準化パワースペクトル密度の一次固有振動数成分, $C_{f}, C_{f}$ : それぞれ 一般化風力の平均風力係数, 変動風力係数, である。

(6)式に示すとおり, 本論文において最大応答変位とは変動成分の みの最大応答值であり平均成分は含まれていない。

\section{2 風カスペクトルのモデル化}

一般化変動風力の基準化パワースペクトル密度(以下, 風力スペク トル $=F(n)$ とする。) は建築物荷重指針・同解説 ${ }^{13)}$ を参照する。通常 の高層建築物では, 風力スペクトルの共振成分は風直交方向のピー ク振動数 $\left(n_{0} B / U \doteqdot 0.1\right)$ 以上となる。この領域では, 風方向・風直交方 向共に両対数軸で概ね直線となる。そこで, 不確かさ伝播解析を簡 便にするために，風力スペクトルを(11)式でモデル化する。

$$
\begin{aligned}
& \frac{n_{0} S\left(n_{0}\right)}{\sigma^{2}}=F\left(n_{0}\right)=a\left(\frac{n_{0} B}{U}\right)^{b} \\
& \text { ここで, } a, b \text { : 風力スペクトルの近似係数 }
\end{aligned}
$$

不確かさ伝播解析を行う場合には各因子に関する偏微分を行うが， 風力スペクトルを簡素化された(11)式で近似することにより偏微分 が格段に容易になり，かつ伝播の状況も把握し易くなる。

辺長比( $D / B, D$ :建物奥行:, $B$ :建物幅)が 0.33 から 2.0 の風力スペクト ルをFig.1に示す。図中には(11)式で D/B=1 の場合の近似状況も付記 する。(11)式による近似は, 風方向, 風直交方向共に風直交方向の ピーク振動数 $(\fallingdotseq 0.1)$ 以上の振動数領域を近似する様に決定した。 (11)式は対象とした振動数領域を適切に近似出来そうである。同様 に種々の辺長比における風力スペクトルを(11)式で近似した場合の 近似係数 a,b の值を Table 1 に示す。対数グラフにおける切片となる 近似係数 a 0.0003 から 0.0084 と值に幅が見られるが, 勾配である 近似係数 $\mathrm{b}$ はほぼ-2.2 前後の值となった。

\section{4.風応答予測值への不確かさ伝播解析}

最大応答変位 $y_{\max }$, 最大応答加速度 $\ddot{y}_{\max }$, 平均変位 $\bar{y}$ を求め る際に用いる各パラメーターを不確かさの因子とし, 各因子の不確 かさ量が風応答予測值にどの程度伝播するかを解析的に求める。ま ず, 風応答予測式である(6)〜(10)式を(1)式に当て嵌めて各因子の伝 播量を求める。そして，(4), (5)式により相対感度係数 $C v_{x i}$ を求め, $C v_{x i}$ を考察することにより各因子の不確かさが風応答予測值へ伝播 する際の増幅あるいは減少の状況を検討する。

対象とする因子は, 建物固有周期 $n_{0}$, 減衰定数 $h$, 設計風速 $U$,
平均および変動風力係数 $C_{f}, C_{f}$, , パワースペクトル密度の共振成分 $F_{L}$, 計 5 因子である。検討に際し風応答予測で想定した建物諸元を Table 2 に示す。減衰定数は, 文献 ${ }^{14)}$ を参照し $2 \%$ とした。ここで, 各因子が変化した場合を考察するために Table 2 に示す因子の值を 基準 $(=1.0)$ とし，その值から $0.5 \sim 1.5$ 倍( $\alpha_{x i}$ と定義する。)に変化させ た。平均変位, 最大応答変位, 最大応答加速度の相対感度係数 $C x i$ をFig.2 に示す。本研究で対象とした因子は概数互いに無相関と仮 定できる。そこで, 図中には相対感度係数を(2)式で合成したトータ ルの相対感度係数 $C_{\text {all }}$ も付記する。 $C_{\text {all }}$ は, 各因子の不確かさ量が同 等の場合の不確かさ伝播量に相当する。なお付録には，各因子に関 する(1)式の伝播量, 相対不確かさ量 $R p_{x i}$, ならびに相対感度係数 $C x i$ の導出を示す。

まず，平均変位について考察する。平均変位では，平均風力係数 $C_{f}$ の相対感度係数 $C_{c f}$ は何れの $\alpha_{c f}$ においても 1.0 となり，このこと から平均風力係数 $C_{f}$ の不確かさは, 増幅もせず減衰もせず, 同じ割 合で応答予測值へ伝播することが分かる。また, 固有振動数 $n_{0}$ この 場合, 建物水平剛性ならびに建物質量の平方根) と設計風速 $U$ の相 対感度係数 $C_{n 0}, C_{U}$ は 2.0 となり, これらの不確かさは 2 倍に増幅 されて平均変位に伝播される。このことから, 例えば平均風力係数 $C_{f}$ の精度よりも設計風速 U の精度が重要であることがわかる。平均 変位は $\alpha_{x i}$ の值によらず相対感度係数 $C v_{x i}$ は一定となっている。

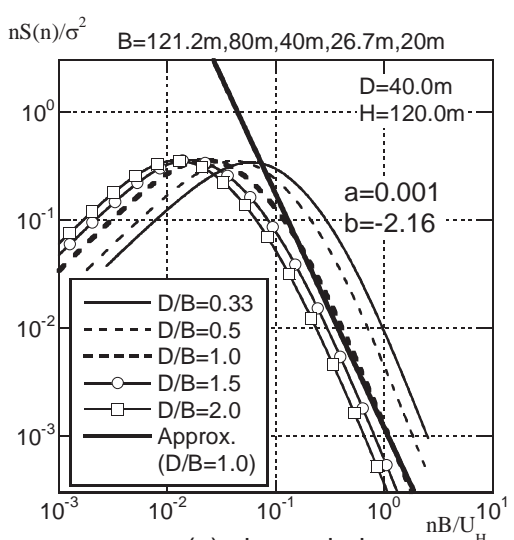

(a) along-wind

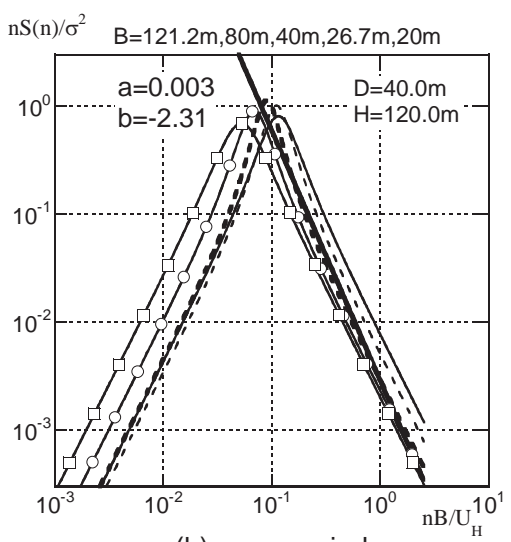

(b) across-wind

Fig.1 Power Spectra Densities of Wind Force

Table 1 Parameter "a" and "b" of Eq.(11)

\begin{tabular}{c|c|c|c|c|c|c|}
\hline & $\mathrm{D} / \mathrm{B}$ & 0.33 & 0.5 & 1.0 & 1.5 & 2.0 \\
\hline \hline \multirow{2}{*}{ Along-wind } & $\mathrm{a}$ & 0.0084 & 0.0041 & 0.0012 & 0.0006 & 0.0003 \\
\cline { 2 - 7 } & $\mathrm{b}$ & -1.89 & -2.02 & -2.16 & -2.18 & -2.16 \\
\hline \hline \multirow{2}{*}{ Across-wind } & $\mathrm{a}$ & 0.0080 & 0.0053 & 0.0030 & 0.0023 & 0.0020 \\
\cline { 2 - 7 } & $\mathrm{b}$ & -2.18 & -2.30 & -2.31 & -2.19 & -2.06 \\
\hline
\end{tabular}


次に最大応答変位について考察する。最大応答変位の相対感度係 数 $C v_{x i}$ は風方向(Fig.2(b)), 風直交方向(Fig.2(c)) とも概亦同様な傾向 を示している。最大応答変位では, 平均変位と同様に変動風力係数 $C_{f}{ }^{\prime}$ の相対感度係数である $C_{c f}$ は 1.0 で一定である。固有振動数 $n_{0}$ と 設計風速 $U$ の相対感度係数 $C_{n}, \quad C_{U}$ は $\alpha_{\mathrm{n}}, \quad \alpha_{U}$ の值により変化する が 2.0 3.0 の值となり, 平均変位の場合よりも増幅が大きい。一方, 減衰定数 $h$ と風力スペクトル $F$ の相対感度係数 $C_{h}, C_{F}$ は $\alpha$ の值により わずかに変化するが，ほぼ 0.2 から 0.3 の值となる。このことから, 減衰定数 $h$ と風力スペクトル $F$ の不確かさが最大応答変位へ及ぼす 影響は，他の因子に対して小さいと言える。

最大応答加速度への伝播は最大応答変位の場合とほぼ同様である。 ただし固有振動数の相対感度係数 $C_{n 0}$ の夕異なり, 最大応答変位で は2.0〜3.0 に増幅していたが, 最大応答加速度ではほぼ 1.0 となり 伝播の増減はない。

不確かさ伝播の合計量である $C_{\text {all }}$ を各応答予測值で比較すると, 最大応答変位で大きく, 特に風直交方向で最も大きな值となってい る。また, いずれの応答予測值においても建物緒元を変化させても $\left(\alpha_{x i}\right.$ の值を変化させても)相対感度係数の変化は小さい。

\section{5.各因子の不確かさ量}

本章では, 各因子の不確かさ量を既往の研究成果に基づいて定 量的に把握する。検討した因子は前章と同様, 建物振動数 $n_{0}$ (検討 では参考文献の都合上固有周期), 減衰定数 $h$, 設計風速 $U$, 平均お よび変動風力係数 $C_{f}, C_{f}$, 一般化変動風力の風力スペクトル $F$ であ る。なお, 各因子の不確かさ量は, (5)式に代入して風応答予測值 への伝播量を計算するため相対不確かさ量 $\left(=\delta x_{i} / x_{i}\right)$ で表す。

\section{1 建物の固有周期の不確かさ}

建物固有周期の不確かさ量は文献 ${ }^{15}$ ) 付表により求めた。文献 ${ }^{15)}$ 付 表によれば, S 造, RC 造ならびに SRC 造の固有周期の設計值と実 測值の関係はFig.3 に示すとおりである。文献 ${ }^{15)}$ 付表では各建物の 固有周期の設計值と実測值が長辺方向と短辺方向に分けて整理され ているため, 本論文でも分けて図化した。建物固有周期は，いずれ の構造においても実測值の方が設計值に比べて周期が短い。

建物固有周期の不確かさは設計值と実際の值の差異が対象となる 為, ここでは変動係数の代わりに以下の変動比を定義して固有周期 の相対不確かさ量とする。

$$
\frac{\delta x}{x_{d i}}=\sqrt{\frac{\sum_{i=1}^{N}\left\{\left(x_{i}-x_{d i}\right)^{2} / x_{d i}{ }^{2}\right\}}{N-1}}
$$

ここで, $\delta x / x_{d i}$ : 変動比, $x_{i}$ : 実測值, $x_{d i}$ :設計值, $\mathrm{N}:$ :゙ータ数である。 $S$ 造, RC 造の変動比を Table 3 に示す。変動比は, 短辺方向, 長辺 方向毎に文献 ${ }^{15}$ 付表の掲載データ全てと建物高さ $60 \mathrm{~m}$ 以上の場合に ついて求めた。 $\mathrm{S}$ 造, RC 造ならびに SRC 造の固有周期の変動比は, それぞれ $0.21 〜 0.24, \quad 0.17 \sim 0.20,0.32 \sim 0.36$ であった。

Table 2 Specifications of study building model

\begin{tabular}{|c|c|}
\hline Width(B),Depth(D),Heigth $(\mathrm{H})$ & $\mathrm{B}=40 \mathrm{~m}, \mathrm{D}=40 \mathrm{~m}, \mathrm{H}=120 \mathrm{~m}$ \\
\hline 1st Natural Frequency & $0.3 \mathrm{~Hz}$ \\
\hline Damping ratio & $2 \%$ \\
\hline Terrain Category & $\mathrm{III}\left(\alpha=0.2, \mathrm{IH}_{\mathrm{H}}=0.139, \mathrm{LH}_{\mathrm{H}}=200 \mathrm{~m}\right)$ \\
\hline Velocity (at building Height) & $45 \mathrm{~m} / \mathrm{s}$ \\
\hline Mean modal force coefficient $\left(\mathrm{C}_{\mathrm{f}}\right)$ & $0.444($ along-wind) \\
\hline Fluctuating model force coefficient $\left(\mathrm{C}^{\prime}\right)$ & 0.097 (along-wind), 0.157 (across-wind) \\
※ Cf and $\mathrm{Cf}^{\prime}$ are from Ref.13)
\end{tabular}

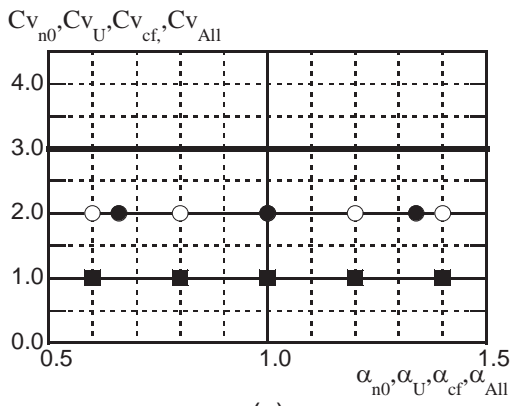

(a)

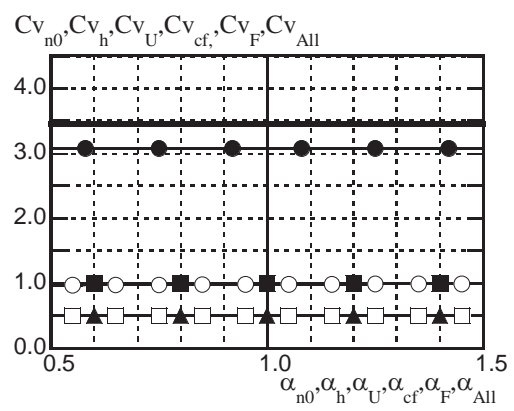

(d)

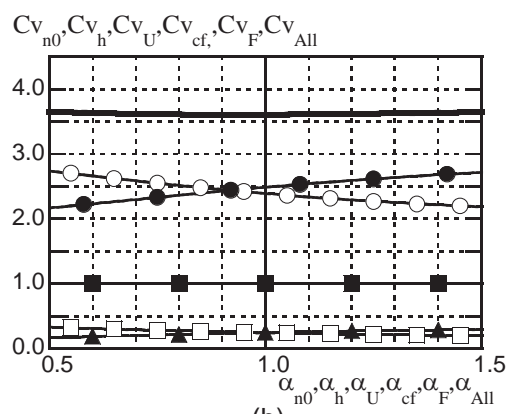

(b)

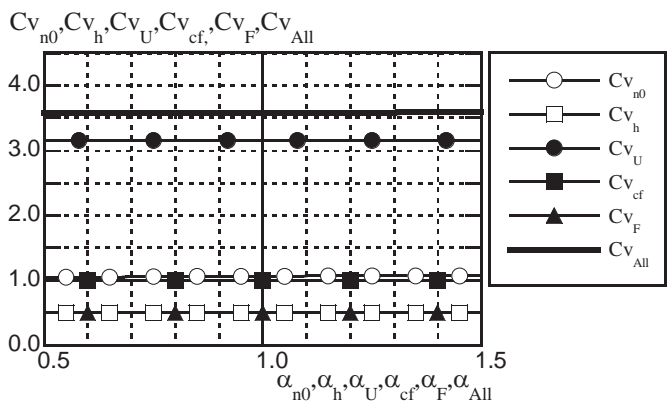

(e)

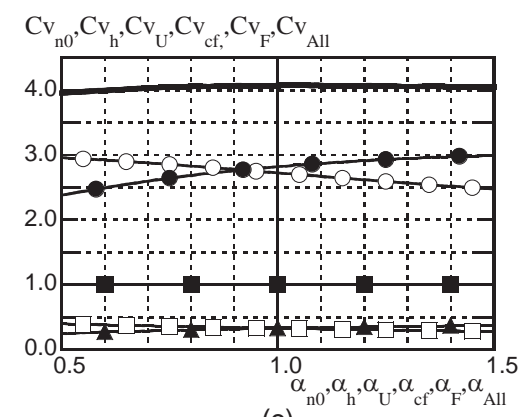

(c)

Fig. 2 Relative uncertainty coefficients of each factor concerning wind response analysis, (a) Mean response displacement, (b)Max. response displacement (along-wind), (c)Max. response displacement (across-wind), (d)Max. response acceleration (along-wind),

(c)Max. response acceleration (across-wind) 


\section{2 建物の減衰定数の不確かさ}

減衰定数の不確かさ量に関しても, 文献 ${ }^{15}$ 付表を参照した。S 造, $R C$ 造ならびにSRC 造の減衰定数と建物高さの関係をFig.4 に示す。 減衰定数はいずれの構造物においてもばらつきが大きい。特に建物 高さが低い場合に顕著である。減衰定数も設計值と実際の值との差 異が対象となる為, 減衰定数の相対不確かさ量も(12)式の変動比で 定義する。文献 ${ }^{15)}$ 付録において設計值がない場合，S 造では $2 \%$, RC 造と SRC 造では 3\%とした。Fig.5 には下式の 1 データごとの変 動比を建物高さごとに示す。

$$
\frac{\delta x_{i}}{x_{d i}}=\left(\frac{x_{i}-x_{d i}}{x_{d i}}\right)^{2}
$$

Fig.5 より, 変動比のばらつきは, 高さによる傾向は少ない。また 構造による差異も明確でない。何れの構造においても減衰定数の設 計値と実測值の差異は, 特異なケースを除いて, 変動比にして概放 最大 0.5 程度の差異がある。

$\mathrm{S}$ 造, RC 造ならびにSRC 造の減衰定数の変動比をTable 4 に示す。 減衰定数の変動比は, 設計值を $2 \%$ あいは $3 \%$ とすると, $\mathrm{S}$ 造で 0.51 〜 0.54, RC 造で 0.51〜0.75, SRC 造で 0.57〜0.69 となる。

\section{3 設計風速の不確かさ}

建築物荷重指針・同解説 ${ }^{13)}$ では, 局所地形と再現期間の変更が無 ければ，設計風速の算出には，基本風速 $\mathrm{U}_{0}$, べき指数 $\alpha$, 境界層高 さ $Z_{G}$ の值が用いられる。従って, 通常の設計風速の不確かさ量はこ れら 3 つ值の不確かさ量が関連する。ここで, 建築物荷重指針・同解

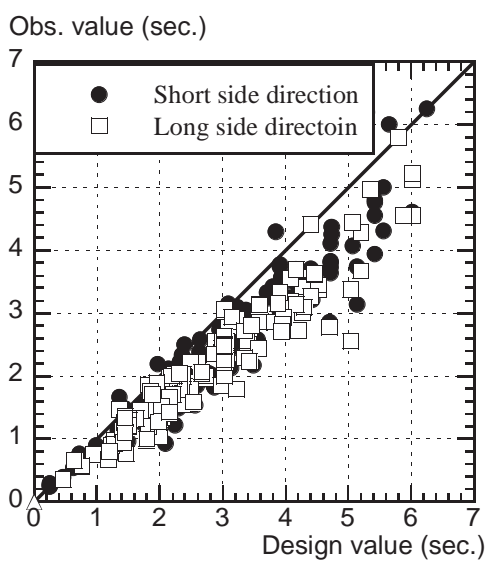

(a) Steel structure

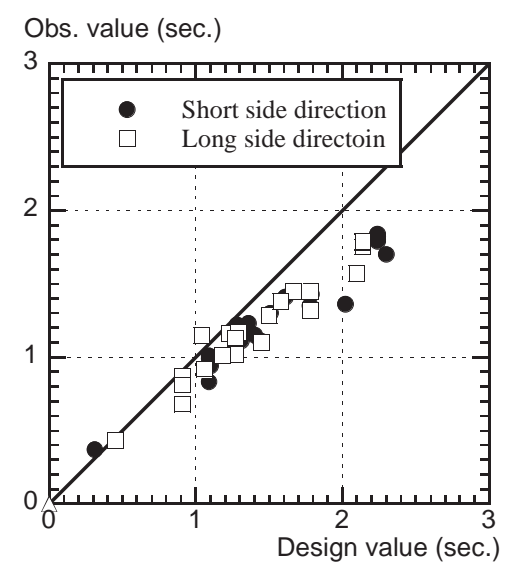

(b) Reinforced Concrete Structure

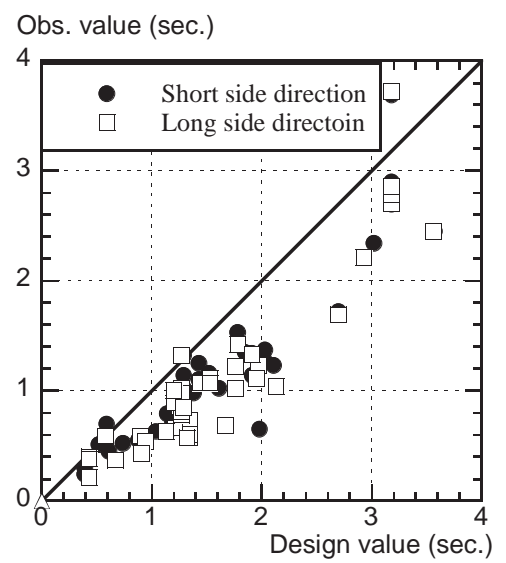

(c) Steel \& R einforced Concrete Structure

Fig.3 Relationship of design values and measurements on natural period ${ }^{15)}$

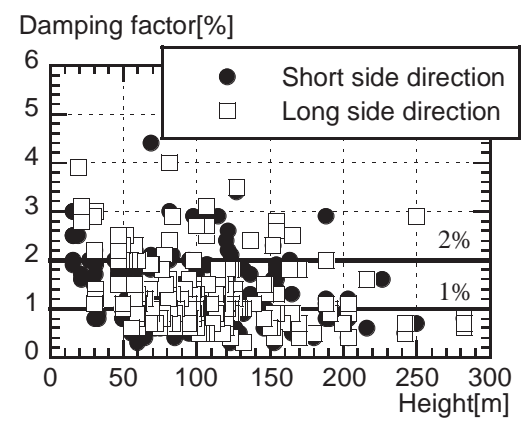

(a) Steel structure

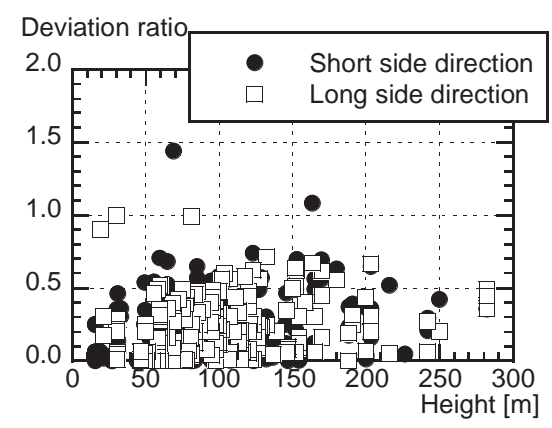

(a) Steel structure

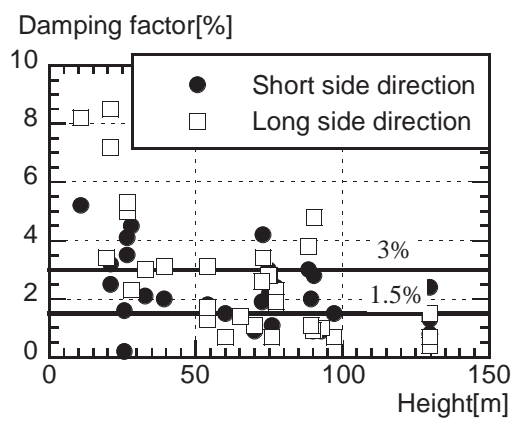

(b) Reinforced Concrete Structure Fig.4 Damping ratio of measurement values ${ }^{15)}$

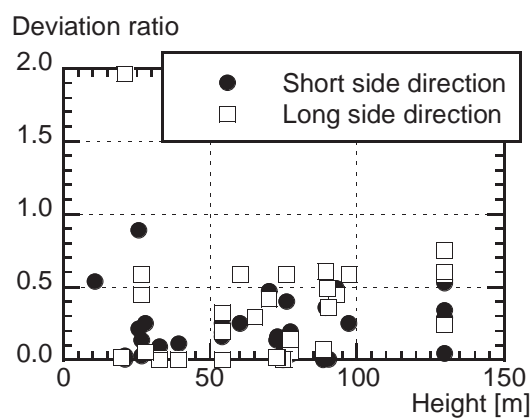

(b) Reinforced Concrete Structure

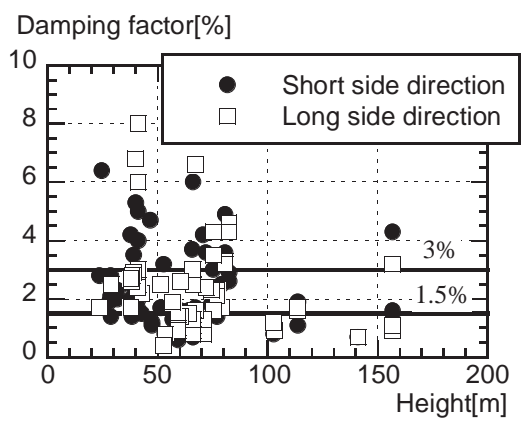

(c) Steel \& Reinforced Concrete Structure

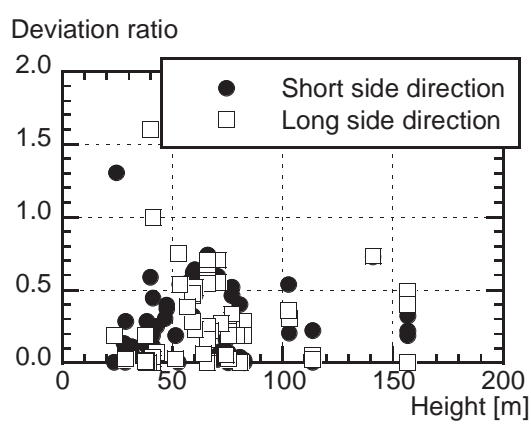

(c) Steel \& Reinforced Concrete Structure

Fig.5 Difference ratios of damping ratio between design values and measurements ${ }^{15}$ 


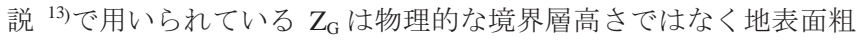
度区分を変更する際に便宜的に用いられていること, 境界層高さ $Z_{G}$ の不確かさ量に関して適切な資料がないこと, の理由により本研究 では省略する。

基本風速 $U_{0}$ の不確かさ量に関しては, 石原ら ${ }^{16)}$ によれば 100 年 再現期待值の標本誤差の全国平均值は $1.8 \mathrm{~m} / \mathrm{s}, 100$ 年再現期待值の 全国平均値は $28.4 \mathrm{~m} / \mathrm{s}$ (1961 年〜1999 年)である。よって基本風速 $\mathrm{U}_{0}$ の不確かさ量は 0.06(=1.8/28.4) と仮定する。

べき指数 $\alpha$ の不確かさは, Li et.al ${ }^{17)}$, 大塚ら ${ }^{18)}$ の市街地における実 測結果を参照した。Li et.al ${ }^{17)}$ の実測では, べき指数 $\alpha$ の平均值は 0.267 , 標準偏差 0.0375 , 変動係数 0.14 (観測高さ $80 \mathrm{~m}, 13 \mathrm{~m} / \mathrm{s}$ 以上の值(デー 夕数 58 個)を使用), 大塚ら ${ }^{18)}$ では, 平均值 0.289 , 標準偏差 0.083 , 変動係数 0.29 (観測高さ $214 \mathrm{~m}, 20 \mathrm{~m} / \mathrm{s}$ 以上の值(32 個)を使用)であっ た。ここで設計風速の算定式 ${ }^{13)}((14)$ 式)より, べき指数 $\alpha$ の不確かさ 量の設計風速 U への相対不確かさ量は(15)式となる。

$$
\begin{aligned}
& U=U_{0} \cdot 1.7 \cdot\left(H / Z_{G}\right)^{\alpha} \\
& \frac{|\partial U / \partial \alpha|}{U} \delta \alpha=\left|\ln \left(H / Z_{G}\right)^{\alpha}\right| \frac{\delta \alpha}{\alpha}
\end{aligned}
$$

べき指数 $\alpha$ の変動係数 $(\delta \alpha / \alpha)$ を上述の 2 実測 ${ }^{17), 18)}$ より 0.2 と仮定し 地表面粗度区分 IV $\left(\mathrm{Z}_{\mathrm{G}}=450 \mathrm{~m}, \alpha=0.20\right)$, 建物高さ $\mathrm{H}=120 \mathrm{~m}$ とすると, べき指数 $\alpha$ の不確かさ量の設計風速への伝播量, 寸なわち相対不確 かさ((15)式)は 0.05 となる。

基本風速 $U_{0}$ とべき指数 $\alpha$ は無相関と仮定すると(2)式の二乗和で 合成できる。すなわち基本風速 $\mathrm{U}_{0}$ の不確かさ量を 0.06 , べき指数 $\alpha$ の不確かさ量の設計風速の伝播量を 0.05 とすると設計風速の相対 不確かさ量は 0.08 となる。

\section{4 風洞実験結果の不確かさ量}

変動風力係数, 平均風力係数, 風力スペクトルは, 風洞実験ある いは建築物荷重指針・同解説 ${ }^{13)}$ により求める。ここで，建築物荷重
指針・同解説 ${ }^{13)}$ の值も風洞実験結果に基づいているため, 風力に関 する各因子の不確かさは全て風洞実験結果の不確かさとする。

風応答予測で用いられる風洞実験結果は，建物全体に作用寸る転 倒モーメントであるが，転倒モーメントの実験值の不確かさに関す る適切な資料が無い為, 文献 ${ }^{19}$ に示される風圧実験データの不確か さを代用する。文献 ${ }^{199}$ には 7 機関で測定された低層建物 $(B: D: H=1: 1: 0.5)$ に作用する変動風圧係数が比較されている。一例と して，屋根面と側面の変動風圧係数をFig.6 に示す。図中には 7 機 関の平均值ならびに標準偏差も付記する。文献 ${ }^{19)}$ より, 変動風圧係 数の変動係数 $(=$ 標準偏差/平均值) は 0.18 0.31(平均值は $0.24 。 1 / 4$ 勾 配流, 風向角 $0^{\circ}$ のデータのみ使用)であった。よって, 変動風力係数, 平均風力係数の不確かさ量は 0.24 とし, 風力の二乗值である風力ス ペクトルは不確かさ伝播解析に則りその 2 倍の 0.48 とする。

\section{5 各因子の不確かさ量の比較}

前節までで検討した各因子の相対不確かさ量 $\delta x_{i} / x_{i}$ をTable 5 に示 す。相対不確かさ量が最も大きいのは減衰定数であり，その值は $\delta h / h=0.5 \sim 1.7$ 程度となっている。建物の減衰定数は解析的に求める のは困難であり，設計段階においては通常経験的に設定される。実 際の建物減衰定数は種々の要因により決定されるため, 実測值にお いても不確かさが大きい。本研究では他の因子と比較しても減衰定 数の不確かさは大きいということが判明した。

次に大きいのは風力スペクトルの不確かさ量であり，本研究の見 積もりでは $\delta F / F=0.48$ となる。風力スペクトルは風力の実験データ の自乗值のため不確かさ量も大きくなる。

固有振動数の相対不確かさ量 $\delta n_{0} / n_{0}$, 平均ならびに变動風力係数の 相対不確かさ量 $\delta C_{f} / C_{f}$ は，減衰定数ならびに風力スペクトルのそれ らと比べて約 1/2 以下の值となる。最も不確かさ量が少ないのは, 設計風速であり，本研究では $\delta U / U=0.08$ となった。設計風速の不確 かさ量はあくまでも再現期間 100 年に対する風速值の不確かさであ るため, 他の因子の相対不確かさ量よりも小さい値となっている。

Table 3 Deviation Ratio of Natural Frequency

\begin{tabular}{c|c|c|c|c|c|}
\hline \multirow{2}{*}{ Structure } & \multirow{2}{*}{ Direction } & \multicolumn{2}{|c|}{ Deviation Ratio } & \multicolumn{2}{c}{ Number of data } \\
\cline { 3 - 6 } & & Total & Over 60m & Total & Over 60m \\
\hline \hline \multirow{2}{*}{ Steel } & Short Side & 0.21 & 0.21 & 192 & 153 \\
\cline { 2 - 6 } & Long side & 0.24 & 0.24 & 168 & 139 \\
\hline \hline \multirow{2}{*}{$\begin{array}{c}\text { Reinforced } \\
\text { Concrete }\end{array}$} & Short Side & 0.19 & 0.20 & 23 & 19 \\
\cline { 2 - 6 } & Long side & 0.17 & 0.18 & 22 & 18 \\
\hline \hline \multirow{2}{*}{ Steel RC } & Short Side & 0.32 & 0.32 & 44 & 33 \\
\cline { 2 - 6 } & Long side & 0.36 & 0.36 & 44 & 33 \\
\hline
\end{tabular}

\begin{tabular}{|c|c|c|c|c|c|c|c|}
\hline \multirow[t]{2}{*}{ Structure } & \multirow[t]{2}{*}{ Direction } & \multicolumn{2}{|c|}{$\begin{array}{c}\text { Deviation Ratio } \\
\text { (design value, } 2 \text { or } 3 \% \text { ) }\end{array}$} & \multicolumn{2}{|c|}{$\begin{array}{c}\text { Deviation Ratio } \\
\text { (design value, } 1 \% \text { or } 1.5 \% \text { ) }\end{array}$} & \multicolumn{2}{|c|}{ Number of data } \\
\hline & & Total & Over $60 \mathrm{~m}$ & Total & Over $60 \mathrm{~m}$ & Total & Over $60 \mathrm{~m}$ \\
\hline \multirow{2}{*}{$\begin{array}{c}\text { Steel } \\
\text { Structure }\end{array}$} & Short Side & 0.51 & 0.54 & 0.75 & 0.71 & 216 & 165 \\
\hline & Long side & 0.52 & 0.51 & 0.79 & 0.70 & 184 & 148 \\
\hline \multirow{2}{*}{$\begin{array}{c}\mathrm{RC} \\
\text { Structure }\end{array}$} & Short Side & 0.51 & 0.52 & 0.91 & 0.66 & 33 & 20 \\
\hline & Long side & 0.75 & 0.62 & 1.70 & 0.87 & 29 & 20 \\
\hline \multirow{2}{*}{ Steel RC } & Short Side & 0.57 & 0.61 & 1.19 & 1.28 & 72 & 37 \\
\hline & Long side & 0.66 & 0.69 & 1.18 & 0.99 & 62 & 37 \\
\hline
\end{tabular}

Table 4 Deviation Ratio of Damping ratio 


\section{6.風応答予測値への不確かさ伝播量}

風応答予測值への相対不確かさ伝播量 $R p_{x i}$ を Fig.7 に示す。Fig.7 中には各因子の相対不確かさ伝播量を(2)式で求めた合成值 $\left(\mathrm{Rp}_{\mathrm{AII}}\right)$ も 付記する。風応答解析で想定して建物特性は Table 2 に示す 4 章で検 討した值と同じである。また, 計算に用いた各因子の相対不確かさ 量は，5章の結果を参考にTable 5 右闌に示寸值を設定した。

まず，平均変位の相対不確かさ伝播量 $R p_{x i}$ について考察する。平 均変位一の相対不確かさ伝播量は固有振動数に起因する不確かさ伝 播量 $R p_{n o}$ が最も大きく 0.46 となる。次いで平均風力係数の不確かさ 伝播量 $R p_{c f}$, 設計風速の不確かさ伝播量 $R p_{U}$ の順となっている。固 有振動数の相対不確かさ伝播量は他の值に比べて 2 倍以上となって いる。3つの因子による相対不確かさ伝播量の合成值は 0.52 である。 以上より, 平均変位の不確かさ量は固有振動数の不確かさ量に大 きく依存していると言える。これは, 固有振動数の相対感度係数 $C V_{n n}$ が 2.0 と大きく, かつ相対不確かさ量 $\delta n_{0} / n_{0}$ も 0.23 と比較的大きい ためと考えられる。

最大応答変位の相対不確かさ伝播量 $R p_{x i}$ は風方向と風直交方向で 定量的にも定性的にも概初同様の傾向を示している。変動風力係数 以外は， $\alpha_{x i}$ の值とともに僅かではあるが值が変化する。ただし，因 子間の相対的な伝播量の傾向は何れの $\alpha_{x i}$ においても同様である。最 大応答変位の相対不確かさ伝播量で最も大きいのは, 平均変位の場 合と同様に固有振動数の不確かさ伝播量であり, その值は $0.5 \sim 0.63$ の值となっている。この值は他の因子による相対不確かさ伝播量の 2 3 倍の值となっている。相対不確かさ伝播量の合成值 $R p_{\text {all }}$ は, 0.62 〜 0.73 であり, このことから最大応答変位の不確かさ量は, 平均変 位と同様に，建物固有周期の不確かさ量に依存している。ここで, 建物固有周期は建物水平剛性と建物質量で決定するため, 建物水平 剛性と建物質量の不確かさ量に依存しているとも言える。

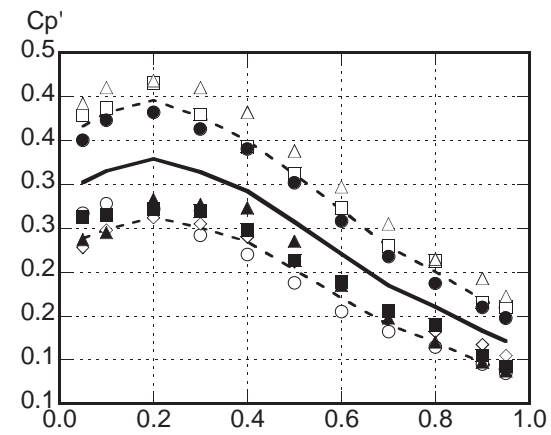

(a) center line of roof
他の因子の相対不確かさ伝播量のなかでは, 変動風力係数の相対 不確かさ量 $R p_{c f}$ が大きく, 風力スペクトルの相対不確かさ量 $R p_{F}$ が 最も小さい。また，相対不確かさ量が最も大きかった減衰定数の相 対不確かさ伝播量 $R p_{h}$ も小さい。これは，4 章で検討した相対感度 係数 $C v_{F}, C v_{h}$ が小さいためである(Fig.2 (b),(c))。

最大応答加速度では, いずれの因子による相対不確かさ伝播量も ほぼ同等の值となる。これは，相対不確かさ量が小さい設計風速で は相対感度係数が大きく, 相対不確かさ量が大きい減衰定数と風力 スペクトルでは，相対感度係数が小さいため，このような結果とな った。各因子の相対不確かさ伝播量の合成值 $R p_{\text {all }}$ は 0.55 であり, 最 大応答変位の合成值 $(0.62 \sim 0.73)$ より小さい。このことより最大応答 変位よりも最大応答加速の不確かさ量が小さいということがわかる。

\section{7.おわりに}

本論文では，風応答解析の信頼性を系統的に検証するため，不確 かさ伝播解析ならびに合成を風応答解析に応用し, 風応答解析で用 いる種々のパラメーター(因子)の不確かさ量の風応答予測值への影 響を検討した。検討では，相対感度係数を定義して各因子の相対的 影響度を解析的に検討した。また，既往の文献により各因子の不確 かさ量を評価した。更に相対感度係数と各因子の不確かさ量から, 風応答予測值への不確かさ伝播量を求め, 風応答予測值の不確かさ がどの因子に強く影響しているかを検討した。検討の結果をまとめ ると以下のとおりとなる。

(1) 平均変位, 最大応答変位において, 相対感度係数が最も大きい 因子，すなわち，風応答予測值へ影響が最も大きい因子は，固 有振動数と設計風速である。一方, 減衰係数ならびに風力スペ クトルの相対感度係数は小さい。

（2）最大応答加速度においては, 固有振動数の相対感度係数は大き

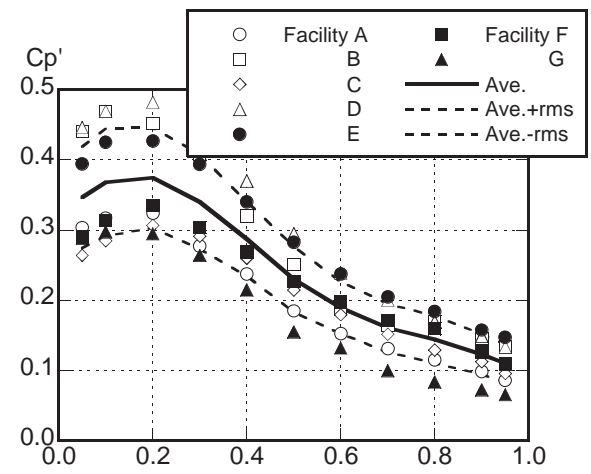

(b) center level of side wall

Fig. 6 Distribution of fluctuating pressure coefficients on low-rise building (B:D:H=1:1:0.5)

Table 5 Values of Relative Uncertainty $\delta x_{i} / x_{i}$

\begin{tabular}{c|c|c}
\hline factor & $\begin{array}{c}\text { deviation coefficient } \\
\text { or deviation ratio }\end{array}$ & $\begin{array}{c}\text { values used in } \\
\text { considertion of } R p_{\text {xi }}\end{array}$ \\
\hline \hline natural frequency & $0.17 \square 0.36$ & 0.23 \\
\hline damping ratio & $0.51 \square 1.70$ & 0.53 \\
\hline velocity & 0.08 & 0.08 \\
\hline fluctuationg wind force coefficient & 0.24 & 0.24 \\
\hline mean wind force coefficient & 0.24 & 0.24 \\
\hline wind force power spectra & 0.48 & 0.48 \\
\hline
\end{tabular}


く, 減衰定数と風力スペクトルのそれは小さい。これは, 平均 変位ならびに最大応答変位と同様の性状だが, 最大応答変位で は大きかった設計風速の相対感度係数は小さい結果となった。

（3）各因子の不確かさ量は減衰係数が最も大きい。次いで風力スペ クトルの不確かさ量が大きく, 最も不確かさ量の小さいのは設 計風速であった。

（4）各因子の不確かさ量の平均変位への伝播量は, 固有振動数の不 確かさ伝播量が最も大きい。すなわち, 平均変位の不確かさは, 建物水平剛性と建物質量の不確かさ量が最も影響しているこ とがわかった。

(5) 最大応答変位への不確かさ伝播量は固有振動数の不確かさ伝 播量が大きい。すなわち最大応答変位の不確かさは固有振動数 の不確かさに大きく依存している。因子の不確かさ量が大きか った減衰定数と風力スペクトルは, 相対感度係数が小さいため, 伝播量としては小さい。

（6）最大応答加速度への不確かさ伝播量は, 各因子の不確かさが同 程度で伝播されている。これは, 因子の不確かさ量が大きいも のは相対感度係数が小さく, 不確かさ量が小さいものは相対感 度係数が大きいためである。

\section{謝辞}

本研究は JSPS 科研費<基盤研究(C) 16K 06594>の助成を受けたも のです。

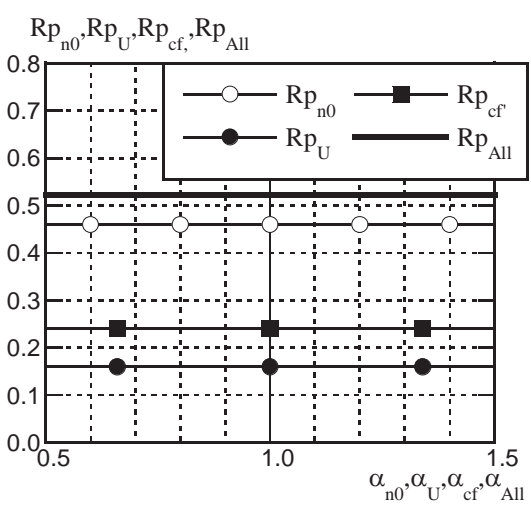

(a)

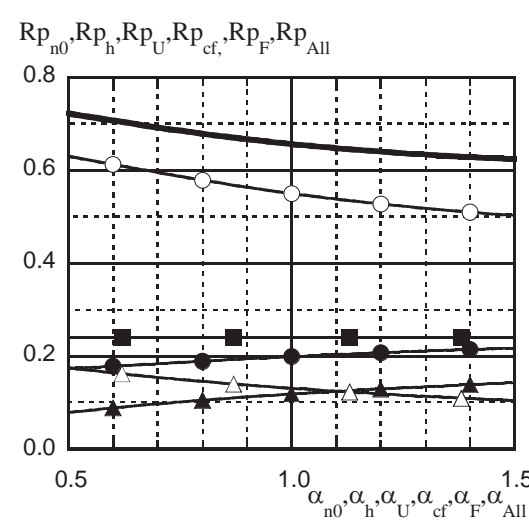

(b)
参考文献

1)Pagnini, L.C.: Model reliability and propagation of frequency and damping uncertainties in the dynamic along-wind response of structures, Journal of Wind Engineering and Industrial A erodynamics, Vol.59, pp.211-231, 1996

2)Pagnini, L.C. and Solari, G.: Gust buffeting and turbulence uncertainties, Journal of Wind Engineering and Industrial A erodynamics, Vol.90, pp.441-459,2002

3)Saranyasoontorn, K. and M anuel, L.: On the propagation of uncertainty in inflow turbulence to wind turbine loads, Journal of Wind Engineering and Industrial A erodynamics, Vol.96, pp.503-523, 2008.5

4) 平井宏幸, 吉江慶祐，佐藤大樹，片桐純治，鶴見俊雄，北村春幸，大熊武 司：風洞実験より得られた層風力のサンプル数が高層建築物の時刻歴応答 評価に及ぼす影響, 日本建築学会技術報告集, 第 18 巻第 39 号, pp.489-494, 2012.6

5)桑村仁，佐々木道夫，加藤勉：降伏耐力のばらつきを考慮した全体崩壊メ カニズム骨組みの設計, 日本建築学会構造系論文報告集, 第 401 号, pp.151-162, 1989.7

6)宅間真, 隈澤文俊, 中埜良昭, 岡田恒男: 構造特性のばらつきが地震応答 量に与える影響に関する研究—その 1 弾性周期の変動と応答スペクトル の関係一，構造工学論文集，Vol.41B，pp.165-170， 1995.3

7)松尾真太郎，岡田忠義，半谷公司，菅野良一：降伏応力のばらつきを考慮 した鋼構造骨組みのエネルギー吸収性能に関する考察，日本建築学会構造 系論文集，第 77 巻第 672 号，pp.273-281，2012.2

8)市橋一郎, 曽根彰, 増田新, 野間樹木：実地震動の時間周波数特性を有寸

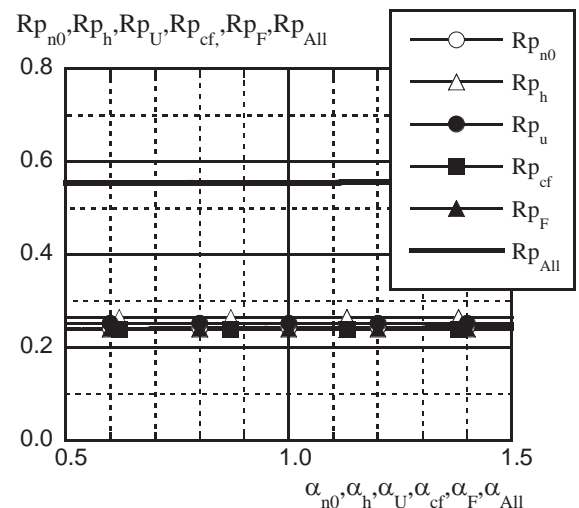

(d)

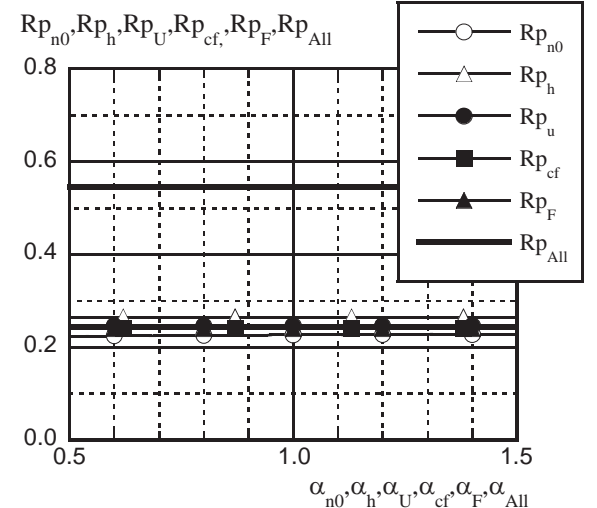

(e)

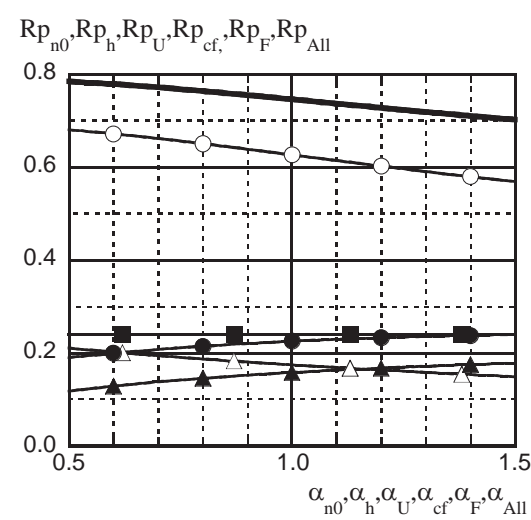

(c)

Fig.7 P ropagation value of relative uncertainty on response analysis on (a) Mean response displacement, (b)Max. response displacement (along-wind), (c)Max. response displacement (across-wind), (d)Max. response acceleration (along-wind), (c)Max. response acceleration

(across-wind) 
る模擬地震波による弾塑性履歴系の最大応答量のばらつきに関する検討, 構造工学論文集, Vol.58B, pp.105-116, 2012.3

9)B ell, S.: M easurement Good Practice Guide No.11(Issue2), A B eginner's Guide to Uncertainty of M easurement, National Physical Laboratory, 2001.3

(https://www.w mo.int/pages/prog/gcos/documents/gruanmanuals/UK_N PL/mgpg1 1.pdf, 参照 2016.9.13)

10)独立行政法人 製品評価技術基盤機構 認定センター: 不確かさの入門ガイ

ド, 2014.5 (http://www.nite.go.jp/data/000050641.pdf，参照 2016.9.13)

11) J ohn R. Taylor(林茂雄, 馬場凉訳) : 計測における誤差解析入門, 東京化学同 人, 2000,3

12)野田博, 丸川比佐夫 : 風環境評価の“ばらつき”に関する考察, 日本風工学 会誌，第 30 巻第 3 号, pp.338-346, 2005

13) 日本建築学会編 : 建築物荷重指針・同解説, 丸善出版, 2015

14) 日本建築センター編：評定・評価を踏まえた高層建築物の構造設計実務, 日本建築センター, 2015

15)日本建築学会編：建築物の滅衰, 丸善, 2000

16)石原孟, 日比一喜, 加藤央之, 大竹和夫, 松井正宏 : 日本各地の年最大風 速データベースの構築と測器補正, 日本風工学会誌第 92 号, pp.5-14, 2002.7

17) Li, O.S., Zhi, L., Hu, F.: Boundary layer wind structure from observations on a $325 \mathrm{~m}$ tower, Journal of Wind Engineering and Industrial A erodynamics, Vol.98, pp.818-832, 2010

18)大塚清敏, 後藤暁, 川口彰久 : 小型ドップラーライダー観測による境界層 の風の日変化, 日本建築学会大会学術講演梗概集, B-1 分冊, pp.93-94, 2010.9

19) 日本建築学会耐風小委員会編：流体計算と風荷重評価シンポジウム資料, 日本建築学会, 1994.11

注

注 1) 野田博: 風応答解析の不確かさに関する研究, 日本建築学会大会学術講 演梗概集, B-1 分冊, pp.197-198, 2013.8

注 2) 野田博: 風応答解析の不確かさに関する研究その.2 各因子の不確か さ量と伝播量, 日本建築学会大会学術講演梗概集, B-1 分冊, pp.151-152, 2014.9

\section{付録 各因子の不確かさ伝播量と伝播係数}

本文で算出した各因子の最大応答加速度, 最大応答変位, 平均変 位, 変動風力の標準偏差, ピークファクターへの不確かさ伝播量の 感度係数 $\partial f\left(x_{i}\right) / \partial x_{i}$, 相対不確かさ伝播量 $R u_{x i}$, 相対感度係数 $C v_{x i}$ を示す。相対感度係数 $C v_{x i}$ は, 相対不確かさ伝播量の算定式の左辺 中三重下線で示す。なお, 一般化風力のパワースペクトル密度(風力 スペクトル)は本文(11)式を参照されたい。

\section{付録 1.最大応答加速度への不確かさ伝播解析}

1)ピークファクター ; $g_{p}$

$$
\begin{aligned}
& \frac{\partial \ddot{y}_{\text {max }}}{\partial g_{p}}=\frac{\sigma_{f}}{m} \sqrt{\frac{\pi}{4 h} \cdot \frac{n_{0} S\left(n_{0}\right)}{\sigma_{f}{ }^{2}}}=\frac{\ddot{y}_{\max }}{g_{p}} \\
& R u_{g p}=\frac{\left|\partial \ddot{y}_{\max } / \partial g_{p}\right| \delta g_{p}}{\ddot{y}_{\max }}=1 \cdot \frac{\delta g}{g_{p}}
\end{aligned}
$$

2)変動風力の標準偏差； $\sigma_{f}$

$$
\begin{gathered}
\frac{\partial \ddot{y}_{\max }}{\partial \sigma_{f}}=\frac{g_{p}}{m} \sqrt{\frac{\pi}{4 h} \cdot \frac{n_{0} S\left(n_{0}\right)}{\sigma_{f}^{2}}}=\frac{\ddot{y}_{\max }}{\sigma_{f}} \\
R u_{\sigma f} \frac{\left|\partial \ddot{y}_{\max } / \partial \sigma_{f}\right| \delta \sigma_{f}}{\ddot{y}_{\max }}=1 \cdot \frac{\delta \sigma_{f}}{\sigma_{f}}
\end{gathered}
$$

3)パワースペクトル密度の共振成分 ; $F_{(n 0)}$

$$
\begin{aligned}
& \frac{\partial \ddot{y}_{\max }}{\partial F_{(n 0)}}=\frac{1}{2} g_{p} \frac{\sigma_{f}}{m} \sqrt{\frac{\pi}{4 h} \cdot \frac{1}{F_{(n 0)}}}=\frac{1}{2} \frac{\ddot{y}_{\max }}{F_{(n 0)}} \\
& R u_{F L}=\frac{\left|\partial \ddot{y}_{\max } / \partial F_{(n 0)}\right| \delta F_{(n 0)}}{\ddot{y}_{\max }}=\underline{\underline{\underline{2}}} \cdot \frac{\delta F_{(n 0)}}{F_{(n 0)}}
\end{aligned}
$$

4)減衰定数 ; $h$

$$
\begin{aligned}
& \frac{\partial \ddot{y}_{\max }}{\partial h}=-\frac{1}{2} g_{p} \frac{\sigma_{f}}{m} \sqrt{\frac{\pi}{4 h} \cdot \frac{n_{0} S\left(n_{0}\right)}{\sigma_{f}^{2}}} \cdot \frac{1}{h}=-\frac{1}{2} \frac{\ddot{y}_{\max }}{h} \\
& R u_{h}=\frac{\left|\partial \ddot{y}_{\max } / \partial h\right| \delta h}{\ddot{y}_{\max }}=\frac{1}{\underline{2}} \cdot \frac{\delta h}{h}
\end{aligned}
$$

5)固有振動数; $n_{0}$

$$
\begin{aligned}
& \frac{\partial \ddot{y}_{\max }}{\partial n_{0}}=\left(2 \ln \left(600 n_{0}\right)+1.2\right)^{1 / 2} \frac{\sigma_{f}}{m} \sqrt{\frac{\pi}{4 h} a\left(\frac{n_{0} B}{U}\right)^{b}} \\
& \cdot\left\{\left(2 \ln \left(600 n_{0}\right)+1.2\right)^{-1}+\frac{1}{2} b\right\} \cdot \frac{1}{n_{0}} \\
& R u_{n 0}=\frac{\left|\partial \ddot{y}_{\max } / \partial n_{0}\right| \delta n_{0}}{\ddot{y}_{\max }}=\underline{\underline{\left\{\left(2 \ln \left(600 n_{0}\right)+1.2\right)^{-1}+\frac{1}{2} b\right\}} \cdot \frac{\delta n_{0}}{n_{0}}}
\end{aligned}
$$

6)設計風速；U

$$
\begin{aligned}
& \frac{\partial a_{\max }}{\partial U}=\left(2-\frac{1}{2} \beta\right) \cdot g_{p} \cdot \frac{\sigma_{f}}{m} \sqrt{\frac{\pi}{4 h} a\left(\frac{n_{0} B}{U}\right)^{b}} \cdot \frac{1}{U} \\
& R p_{U}=\frac{\left|\partial a_{\max }\right| \partial U \mid \delta U}{a_{\max }}=\left\{2-\frac{1}{2} b\right\} \cdot \frac{\delta U}{U}
\end{aligned}
$$

\section{付録 2.最大応答変位への不確かさ伝播解析}

1)ピークファクター ; $g_{p}$

$$
\frac{\partial y_{\max }}{\partial g_{p}}=\frac{\sigma_{f}}{k} \sqrt{1+\frac{\pi}{4 h} \cdot \frac{n_{0} S\left(n_{0}\right)}{\sigma_{f}^{2}}}=\frac{y_{\max }}{g_{p}}
$$

$$
R p_{g p}=\frac{\left|\partial y_{\max } / \partial g_{p}\right| \delta g_{p}}{y_{\max }}=1 \cdot \frac{\delta g}{g_{p}}
$$

2)変動風力の標準偏差； $\sigma_{f}$

$$
\frac{\partial y_{\max }}{\partial \sigma_{f}}=g_{p} \frac{1}{k} \sqrt{1+\frac{\pi}{4 h} \cdot \frac{n_{0} S\left(n_{0}\right)}{\sigma_{f}^{2}}}=\frac{y_{\max }}{\sigma_{f}}
$$




$$
R p_{\text {of }}=\frac{\left|\partial y_{\max } / \partial \sigma_{f}\right| \delta \sigma_{f}}{y_{\max }}=1 \cdot \frac{\delta \sigma_{f}}{\sigma_{f}}
$$

3)パワースペクトル密度の共振成分； $F_{(n 0)}$

$$
\begin{aligned}
& \frac{\partial y_{\max }}{\partial F_{(n 0)}}=\frac{1}{2} \frac{\pi}{4 h} \frac{1}{\left(1+\frac{\pi}{4 h} F_{(n 0)}\right)} y_{\max } \\
& R p_{F}=\frac{\left|\partial y_{\max } / \partial F_{(n 0)}\right| \delta F_{(n 0)}}{x_{\max }}=\frac{\pi}{8 h / F_{(n 0)}+2 \pi} \cdot \frac{\delta F_{(n 0)}}{F_{(n 0)}}
\end{aligned}
$$

4)減衰定数 ; $h$

$$
\begin{gathered}
\frac{\partial y_{\max }}{\partial h}=-\frac{1}{2} g_{p} \frac{\sigma_{f}}{k} \sqrt{1+\frac{\pi}{4 h} \cdot F_{(n 0)}} \\
\cdot \frac{1}{\left(1+\frac{\pi}{4 h} F_{(n 0)}\right)}\left(\frac{\pi}{4 h} \cdot F_{(n 0)}\right) \cdot \frac{1}{h} \\
R p_{h}=\frac{\partial y_{\max } / \partial h \mid \delta h}{y_{\max }}=\frac{\underline{8 h+2 \pi F_{(n 0)}}}{\underline{8 h}} \cdot \frac{\delta h}{h}
\end{gathered}
$$

5)固有振動数; $n_{0}$

$$
\begin{aligned}
& \frac{\partial y_{\max }}{\partial n_{0}}=\frac{1}{n_{0}} \cdot g_{p} \frac{\sigma_{f}}{\left(2 \pi n_{0}\right)^{2} m} \sqrt{1+\frac{\pi}{4 h} a\left(\frac{n_{0} B}{U}\right)^{b}} . \\
& {\left[\left(2 \ln \left(600 n_{0}\right)+1.2\right)^{-1}-2+\pi a b\left(\frac{n_{0} B}{U}\right)^{b}\left\{8 h+2 \pi a\left(\frac{n_{0} B}{U}\right)^{b}\right\}^{-1}\right]^{(\mathrm{a} 21)}} \\
& R p_{n 0}=\frac{\left|\partial y_{\max } / \partial n_{0}\right| \delta n_{0}}{y_{\max }}=\underline{\underline{\left[\left\{\ln \left(600 n_{0}\right)+1.2\right\}^{-1}-2\right.}} \\
& \left.+\pi a b\left(\frac{n_{0} B}{U}\right)^{b} \cdot\left\{8 h+2 \pi a\left(\frac{n_{0} B}{U}\right)^{b}\right\}^{-1}\right] \cdot{\frac{\delta n_{0}}{n_{0}}}^{(\mathrm{a} 22)}
\end{aligned}
$$

付録 3. 平均変位への不確かさ伝播解析 1)平均風力係数

$$
\frac{\partial \bar{y}}{\partial \bar{C}_{f}}=\frac{1}{2} \rho U^{2} \cdot \frac{1}{k}=\frac{\bar{y}}{\bar{C}_{f}}
$$

$$
\begin{aligned}
& R u_{U}=\frac{\left|\partial x_{\max } / \partial U\right| \delta U}{x_{\max }} \\
& =\left[2-\pi a b\left(\frac{n_{0} B}{U}\right)^{b}\left\{8 h+2 \pi a\left(\frac{n_{0} B}{U}\right)^{b}\right\}\right] \cdot \frac{\delta U}{U}
\end{aligned}
$$

$$
R_{C f} \frac{\left|\partial \bar{y} / \partial \bar{C}_{f}\right| \delta \bar{C}_{f}}{\bar{y}}=1 \cdot \frac{\delta \bar{C}_{f}}{=}
$$

\section{2)固有振動数}

$$
\begin{aligned}
& \frac{\partial \bar{y}}{\partial n_{0}}=-2 \cdot \bar{C}_{f} \frac{1}{2} \rho U^{2} \cdot \frac{1}{(2 \pi)^{2} n_{0}{ }^{3} m}=-2 \frac{\bar{y}}{n_{0}} \\
& R u_{n 0}=\frac{\left|\partial \bar{y} / \partial n_{0}\right| \delta n_{0}}{\bar{y}}=2 \cdot \frac{\delta n_{0}}{n}
\end{aligned}
$$

3)設計風速

$$
\begin{aligned}
& \frac{\partial \bar{y}}{\partial U}=2 \cdot \bar{C}_{f} \frac{1}{2} \rho U \cdot \frac{1}{k}=2 \frac{\bar{y}}{U} \\
& R u_{U}=\frac{|\partial \bar{y} / \partial U| \delta U}{\bar{y}}=2 \cdot \frac{\delta U}{U}
\end{aligned}
$$

付録 4.変動風力の標準偏差への不確かさ伝播解析 1)変動風力係数

$$
\begin{aligned}
& \frac{\partial \sigma_{f}}{\partial C_{f}{ }^{\prime}}=\frac{1}{2} \rho U^{2}=\frac{\sigma_{f}}{C_{f^{\prime}}} \\
& R u_{C f}=\frac{\left|\partial \sigma_{f} / \partial C_{f^{\prime}}\right| \delta C_{f}^{\prime}}{\sigma_{f}}=\underline{1}=\frac{\delta C_{f}^{\prime}}{C_{f}^{\prime}}
\end{aligned}
$$

2)設計風速

$$
\begin{aligned}
& \frac{\partial \sigma_{f}}{\partial U}=2 \frac{1}{2} C_{f} \rho U=2 \frac{\sigma_{f}}{U} \\
& R u_{U}=\frac{\left|\partial \sigma_{f} / \partial U\right| \delta U}{\sigma_{f}}=2 \cdot \frac{\delta U}{U}
\end{aligned}
$$

付録 5.ピークファクターへの不確かさ伝播解析 1)固有振動数

$$
\begin{aligned}
& \frac{\partial g_{p}}{\partial n_{0}}=\frac{\sqrt{2 \ln \left(600 n_{0}\right)+1.2}}{2 \ln \left(600 n_{0}\right)+1.2} \frac{1}{n_{0}}=\frac{g_{p}}{g_{p}^{2}} \frac{1}{n_{0}} \\
& R u_{n}=\frac{\left|\partial g_{p} / \partial n_{0}\right| \delta n_{0}}{g_{p}}=\frac{1}{g_{p}^{2}} \cdot \frac{\delta n_{0}}{n_{0}}
\end{aligned}
$$




\section{UNCERTAINTY PROGAGATIONS ON WIND RESPONSE ANALYSIS OF TALL BUILDINGS}

\section{Hiroshi NODA*}

* Prof., Dept. of Architecture, Faculty of Architecture, Kindai University

In this paper, uncertainty propagation analysis was applied to investigate accuracy of wind response prediction of high raise buildings and influence of uncertainties in each parameter used in wind response analysis. A new parameter which is "related sensitivity coefficient" concerning propagation was defined to consider wind response prediction more analytically and efficiently. The values of uncertainties of each parameter were also investigated on the basis of prior literature. Furthermore, the accuracy of wind response predictions calculated by spectra-modal analysis was revealed from investigation of related sensitivity coefficients and values of uncertainties of each parameter.

The following conclusions can be drawn from this study.

1) Regarding the mean and maximum response displacements, the natural frequency and design wind speed had the largest influence exerted by any factor on the wind response predictive value. On the contrary, the relative sensitivity coefficient was low for the damping ratio as well as the resonance wind force spectrum (i.e., resonance component of the wind power spectrum density of the fluctuating wind force).

2) Regarding the maximum response acceleration, the relative sensitivity coefficient was high for the natural frequency and low for the damping ratio and the resonance wind force spectrum. It had the same characteristics with the mean response displacement. However, the design wind speed with high sensitivity in the maximum response displacement had low sensitivity for the maximum response acceleration.

3) The damping ratio had the highest uncertainty value for any factor. The resonance wind force spectrum had the next highest uncertainty value. The lowest uncertainty value was the design wind speed.

4) The uncertainty propagation value to the mean response displacement was larger for the natural frequency than any other factor. That is, the uncertainty of the mean response displacement was affected by the uncertainty of the building's horizontal stiffness and mass.

5) The uncertainty propagation value to the maximum response displacement was the highest for the natural frequency. That is, the uncertainty of the maximum response displacement was largely dependent on the uncertainty of the natural frequency. The damping ratio and the resonance wind force spectrum had high uncertainty. However, their propagation values were low because their relative sensitivity coefficients were low.

6) The uncertainty propagation value to the maximum response acceleration was similar for all factors because the relative sensitivity coefficient was low, where the uncertainty of factors was high, and the relative sensitivity coefficient was high, where the uncertainty of factors was low. 